International Journal of Current Advanced Research

ISSN: O: 2319-6475, ISSN: P: 2319 - 6505, Impact Factor: SJIF: 5.995

Available Online at www.journalijcar.org

Volume 6; Issue 3; March 2017; Page No. 2595-2603

DOI: http://dx.doi.org/10.24327/ijcar.2017.2603.0054

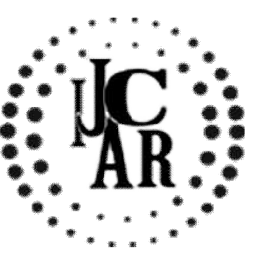

Review Article

\title{
AURANGABAD: A WEAVING TOWN OF HERITAGE TEXTILES
}

\author{
Aditi Bhatia., Simmi Bhagat And Ritu Mathur
}

Department of Fabric and Apparel Science, Lady Irwin College, Delhi University

\section{A R T I C L E I N F O}

\section{Article History:}

Received $18^{\text {th }}$ December, 2016

Received in revised form $16^{\text {th }}$ January, 2017

Accepted $26^{\text {th }}$ February, 2017

Published online $28^{\text {th }}$ March, 2017

\section{Key words:}

Paithani saree, Himroo, Brocade, Zari, Pit loom. \begin{abstract}
A B S T R A C T
The story of Indian textiles is a fascinating picture of the alchemy of handloom spinning, weaving and the magic in the skill of our weavers who carry the wisdom of their forefathers. The historical antecedents ofsuch fabrics are also found in the state of Maharashtra. The Paithanis of Maharashtra with loom embroidered designs in silk on gold and silver ground work is no exception.Other famous woven craft of Maharashtra is the Himroo. Both these are practiced in the district of Aurangabad. This review paper appraises details about the rich and exquisite Paithani weaving techniques and patterns and also briefly focuses on Himroo textiles as the weavers and weaving units of both crafts are the same.
\end{abstract}

Copyright $₫ 2017$ Aditi Bhatia et al. This is an open access article distributed under the Creative Commons Attribution License, which permits unrestricted use, distribution, and reproduction in any medium, provided the original work is properly cited.

\section{INTRODUCTION}

Brocades of India, with brilliance of colour and richness of composition are inseparable from the idea of magnificence intended to charm, captivate and dazzle. Indian brocades are celebrated worldwide for their finery e.g. brocades of Banaras, Surat, Bhopal, Tanjore, Madras, Ahmedabad, Murshidabad, Oudh and Paithan.

Maharashtra has undeniably vast textile wealth and abundant weaving regions. It is also amongst the traditional centre for the cultivation of cotton and silk, hand spinning and weaving (Fig.1). Maharashtra can be proud of its traditional weaving techniques that have continued to flourish even after centuries of their origin.

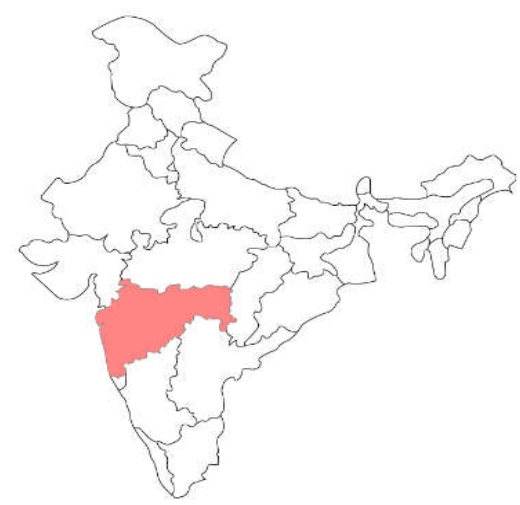

Source: mapsofindia.com Fig.1 Map of India highlighting and Maharashtra

*Corresponding author: Aditi Bhatia,

Department of Fabric and Apparel Science, Lady Irwin College, Delhi University
Traditionally, Marathi women commonly wore the sari, often distinctly designed according to local cultural customs.

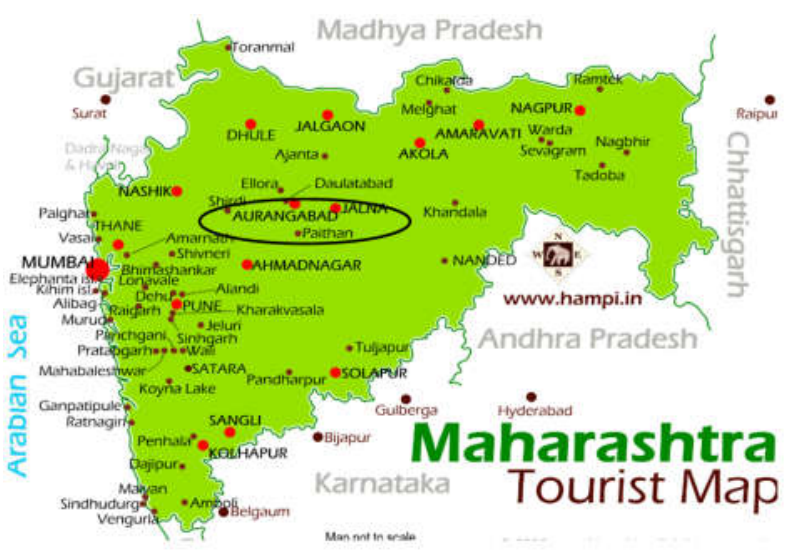

Source: www.hampi.com

Fig.2 Map of Maharashtra highlighting Aurangabad Paithan

Aurangabad is a district in Maharashtra, named after Mughal emperor Aurangzeb. Malik Ambar, the Prime Minister of Murtaza Nizam, Shah of Ahmadnagar founder of this site named it Fatehnagar. In 1653, when Mughal prince Aurangzeb was appointed the viceroy of the Deccan for the second time, he made Fatehnagar his capital and renamed it Aurangabad. Presently Aurangabad is also known as the tourism capital of Maharashtra. Handloom weaving industry is famous and has thrived here since long. Himroo is one of the traditional woven craft that belonged here. Another magnificent and graceful handwoven textile Paithani is also synonymous to Aurangabad. It is produced in Paithan, a city that is part of Aurangabad District (Fig.2). 
Paithani saris are the most popular sarees of Maharashtra that are symbolic of the national heritage, varied design repertoire and undying dedication of the weaver. The absolute beauty of these sarees is intense and speaks as much of the skill of the craftsman as of his imagination (Anonymous, 1980).

\section{METHODOLOGY}

This paper analyses various scholarly works, project reports, and government documents to determine and understand the history, technique and patterns used in Paithani saree weaving. As mentioned earlier, Paithan is a town falling under Aurangabad district and Aurangabad is also known for another traditional woven craft called Himroo. Most of the Himroo weaving centres also have a Paithani saree loom. Athough both the textiles are dissimilar in terms of weave, raw material, designs, motifs, colours andend products yet it is produced by same set of weavers. Hence Himroo is also discussed briefly in this paper. A detailed review paper titled 'Himroo: Earliest Industry of Aurangabad' was published in International Journal of Applied Home Science, Dec 2016.

Around 40 studies were screened for this review paper. The information thus gathered and compiled has been discussed in the following sections.

\section{Paithani Sarees}

Paithani is one of the richest and most artistic sarees which got its name from the village where it is produced, Paithan in Maharashtra. The brocades from the Deccan prefer the original Indian traditions of depicting animal and bird figures. Paithanis of Maharashtra also follow this tradition of clean lines inspired by Ajanta paintings or objects associated with Vaishnavite traditions, since a large number of Krishna worshippers for several centuries have been associated with weaving.

The hand-woven sarees, reminiscent of craftsman's dedication to his craft, is a work of labour and takes as much as a year to produce. Symbolic decorations have made Paithani a unique possession of Maharashtrian bride. It has a very ornatepallavand is worn by Maharashtrian women on special occasions (Fig.3).

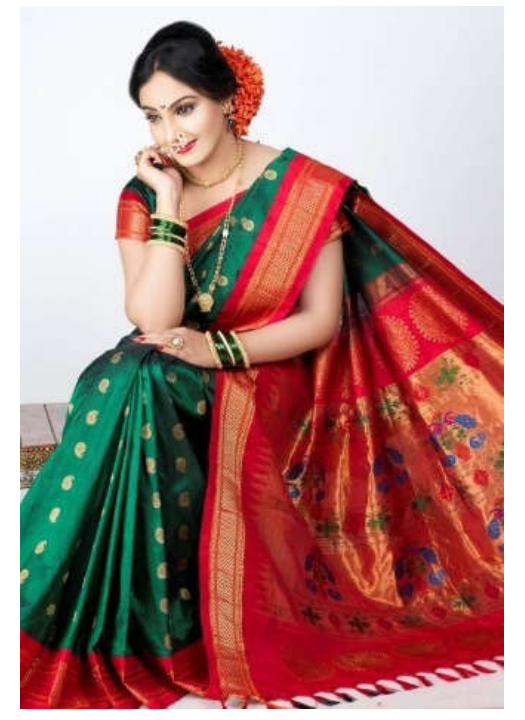

Source: http://onlypaithani.com

Fig.3 Maharashtrian Bride in a Paithani Saree

\section{History}

The Paithanis have lineage dating back to 300-200 B.C. when it was produced in its original form. Cotton, silk, gold and silver were the raw materials in these sarees which find references in the Epics. Mahabharata has citations of Paithani textiles in the endless saree of Draupadiand mythological scenes like Chandrasahit-Rohini and NalaDamyanti. Sir George Watt (Indian art at Delhi, 1903 catalogue) described that the cotton Paithanis were also as popular as the silk ones.

“........a cotton sari, dark blue with borders in gold, the scrollsbeing in metallic blue acutely bent and interlaced with a green scroll, the later having pink and orange flowers. The end piece is a plain gold panel

surrounded by the bordering of the same......."

The Marathas (1295 - 1858 A.D.) succeeded the Mughals and extended their countenances to the sarees from Paithan. Two distinct forms of Paithani Sarees could be recognised during this time. One with the design from the Mughal atelier conceived on the border and pallav with all over design of butis, stripes or checks. The second kind of saree had small diamond forms worked by the dobby attachments on the border called Narlikat with pallav and field of the saree in all over layout.

Presently these saris are woven in Paithan and Yeola in Aurangabad. An enormous amount of labour, skill and sheer expense of materials are used to create the best of these saris that rivalled the other luxury fabrics of the Mughal court. Paithani saris had royal associations till twentieth century (Gupta,1990).

\section{Traditional weaving process}

Originally this saree was woven with the body in dyed cotton yarns. Silk and zari were mainly used on the base of the pallav and the borders, on which motifs and patterns were created in the tapestry technique. The use of zari, the complexity of weaving and purity of colours in motifs impart the Paithani its unique character (Gillow, Barnard, 1993).

Spinning, dyeing and weaving of silk, drawing of gold or silver zari and skilled craftsmen formed the materials, methods and men of the organisational framework of the industry involved in Paithani production.

\section{Preparation of the yarn}

Paithan produced raw silk in bulk from cultivated cocoons as the climatic conditions were suitable along with the availability of cheap labour and abundance of Mulberry trees. Reeling and degumming: Cocoons obtained were stifled by sun drying or by steam and stored without any damage to the shells. The cocoons unfit for reeling were sorted and discarded. The gum of silk was softened by cooking of cocoons in water and were brushed to facilitate reeling. Floating ends of several cocoons were joined together by skilled people and reeled to obtain a single filament on a charkha. Hanks formed were sent for degumming. Silk skeins were degummed using a solution of Sajji (carbonate of soda) or Aritha (Soap). It was boiled in this solution for two to three hours and rubbed with palms and finally rinsed with tepid water.

Sorting: The silk was sorted by throwing it on a three feet round bamboo cage called phalka that surrounded a central 
handle about two feet long. The sorter, generally a woman, fastened the end of the hank to a smaller reel known as asari. The quality of the fibre on the skein was uneven hence various reels were filled according to their quality. The reeler wound the silk from 4-5 asaris to obtain even yarn (Fig. 4) (Gupta, 1990).

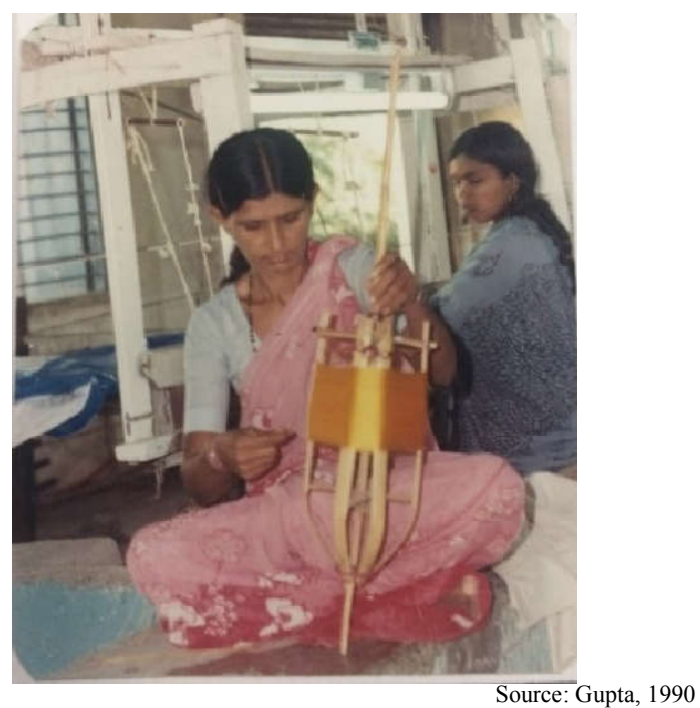

Fig. 4 Winding on Asari

Spinning: Spinning was done using a small wheel for which the silk was wound from reels to bobbins called garolis made of hollow reed. By means of wheel and axle the fibres of each bobbin were twisted together and guided through a glass ring around drum and then reeled on a small reel or phalki. Two yarns were used for making warp yarns and they were wound again on the reel to obtain weft yarn (four yarns).

Bleaching: The silk hanks were exposed to fumes of sulphur for bleaching. A two feet high basket was laid bottom up with holes for free passage of air. In the bottom and sides of the basket a dish containing live coal and sulphur pieces was kept. The damp yarns spread over the basket and soaked with sulphur fumes. Alternatively, silk was boiled in an alkaline solution called ukhar. It was prepared by boiling slaked lime and carbonate of soda. While boiling, silk was not allowed to stay in the solution for long.

After boiling silk was washed and dipped in solution of alum and kept for three nights and washed again.

Dyeing:Silk used for weaving was dyed by rangari by natural dyes extracted from roots and barks of trees, leaves, flowers, fruits of plants and shrubs. The various dyes obtained were of vegetable origin. Cochineal was obtained from Coccus cacti for red, Pistachio from Pistaciavera, Isparek from a kind of Delphinium for yellow, Myrobalam from Terminalia chebula for black, Babhul from flowers of Acacia arabica, Catechu from woods and barks of Acacia catechu, Indigo or nil was juice of leaves of Indigofera tinctorial and Halad or turmeric from roots of Curcuma longa for orange (Gupta, 1990).

Zari: Gold or silver yarns called kallabattu were of local manufacture and were prepared by twisting the flattened gold or silver wire badla on silk core yarn.

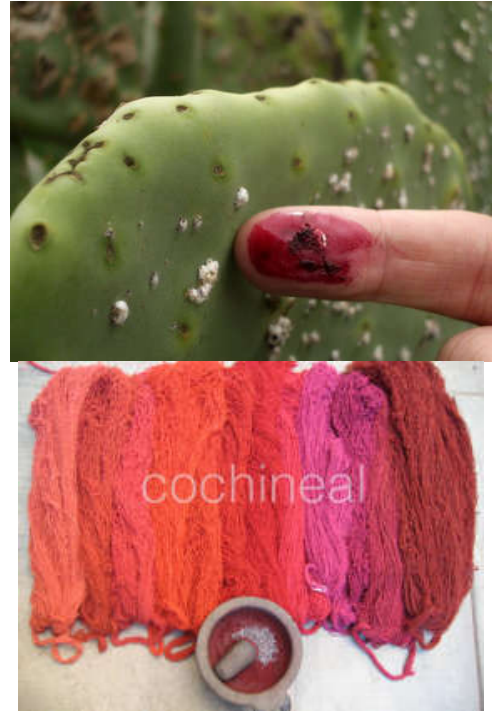

Source: www.alamy.com

Fig.5 Cochineal obtained from coccus cacti plant

Tarkash or the zari wire makers, gilded a silver bar about seven inches and weighing forty tolas, with purest gold leaf. For silver zari, no such coating was given. The coil of gold and silver wire were handed over to the taniah or fine wire drawer who passed it through successive holes till each tola was lengthened to about eight hundred yards and the wire became as fine as hair.

The warps of silk were stretched on a tansala, a pair of wooden upright bars with rows of glass rings for the warps to pass (Fig. 6). For silk weft, the reel and a small wheel were used to fill the reed called likhadi. The yarns from reel were moistened with the gum and wound on the likhadi fixed on the axle of the wheel by working the wheel. The gum was spread evenly by passing the yarns through the fingers (Gupta, 1990).

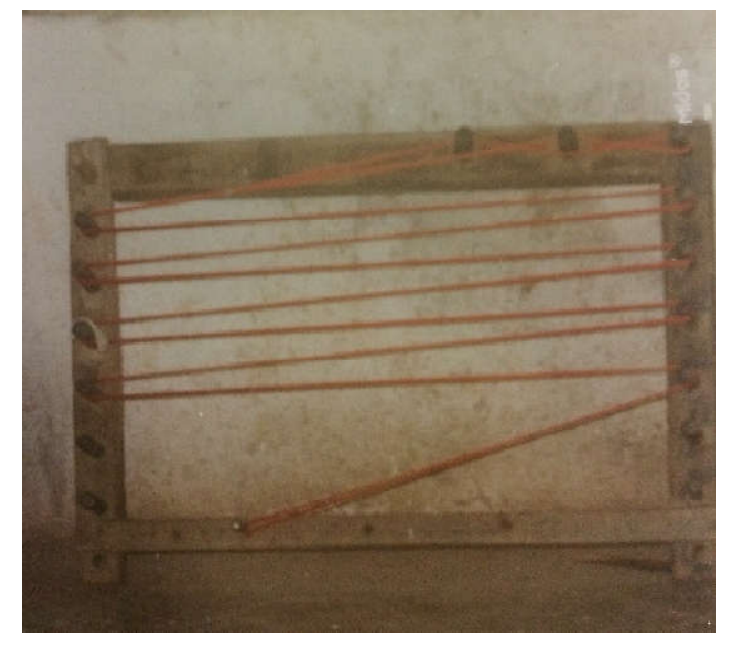

Fig. 6 Warping on Tansala

Source: Gupta, 1990

\section{The Loom}

The warps were then made ready on the loom (Fig.7). The heddle was filled according to the pattern of the borders passing the warp yarns through the loops in the cords of the different heddles. Simultaneously, the yarns were threaded between the teeth of the reed phani, and the whole length of 
warp yarns were arranged. The weavers sat in a large pit which was 8-15 feet long and 4-7 feet broad. In front of the weaver was the cloth beam called turai and in the pit the foot board to lower and raise the warps. The warps, after the pit where weavers sat, stretched to the warp beam. Behind the heddles, horizontal rods were thrust between the upper and the lower yarns of warp. The warp beam was held tight by a rope passing over a pulley and fastened close to the weaver. This rope was loosened as the saree was woven. The silk and zari yarns were wound on the shuttles and small cloth pirns, by the weavers after setting up the loom.

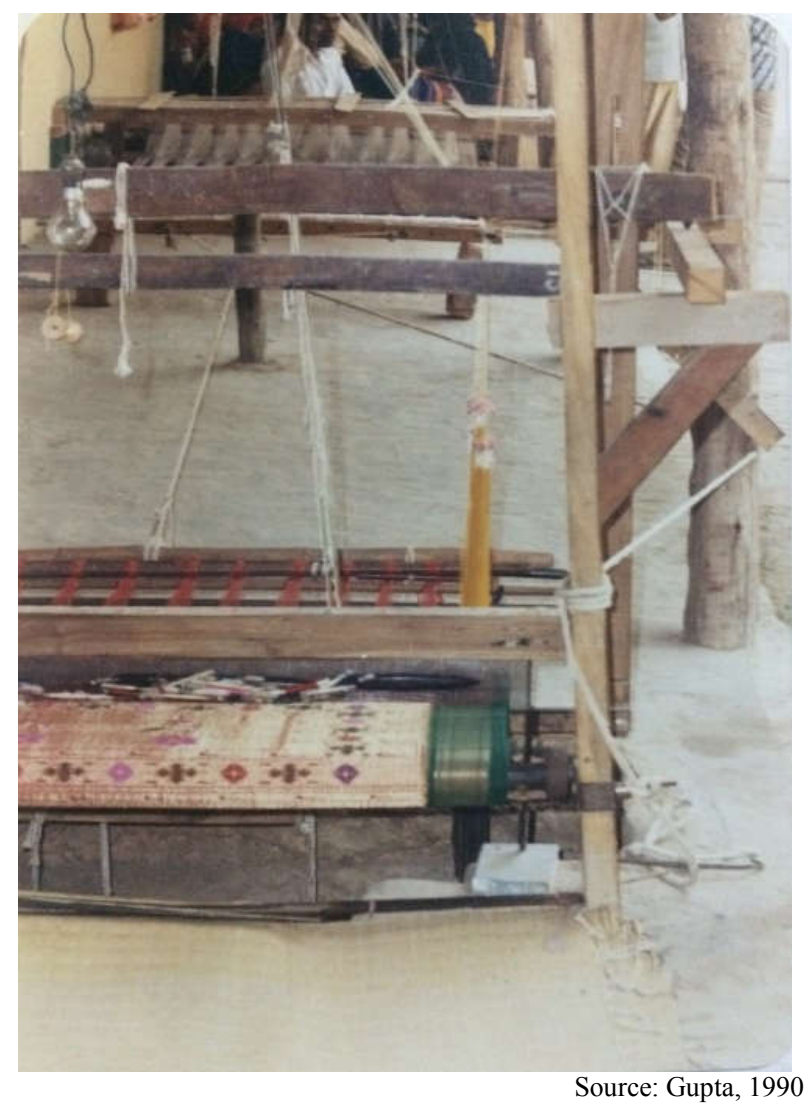

Fig. 7 Traditional Pit Loom

\section{Weaving process}

The weaver with his fingers would lift the warps for a particular colour of the motif and pass the pirn through. The number of pirns depended on the colours to be used and the times motif appeared along the width of the saree. Two-and-ahalf-inch border needed fifteen to twenty pirns. The shed was formed of a plain weave and shuttle passed through these and the weft having been driven back by the beat of the sley was returned. The weaver again drew the yarns with his fingers but first the yarns lying close to each other were inter locked and then passed between the warps as in the design. Shed was formed after interlocking and the shuttle passed. Hence the tillies passed the warps over a greater or lesser number, depending on the width of the design. The process was slow, sometimes not more than half an inch was woven in twelve hour working day. It was through the vine of asavali motif were climbing slowly, almost imperceptibly up the border like a living vine putting out flowers every now and then till having reached the trellis it would spread magnificently across the whole width of the pallav (Fig. 8). The pallav and the borders could also be woven separately on a smaller loom and sewn to the sari later (Fig.9) (Gupta, 1990).

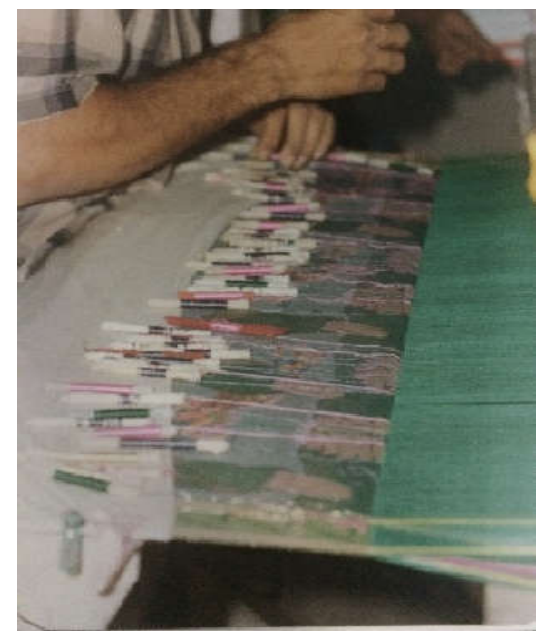

Fig. 8 Pallav weaving

Source: Gupta, 1990

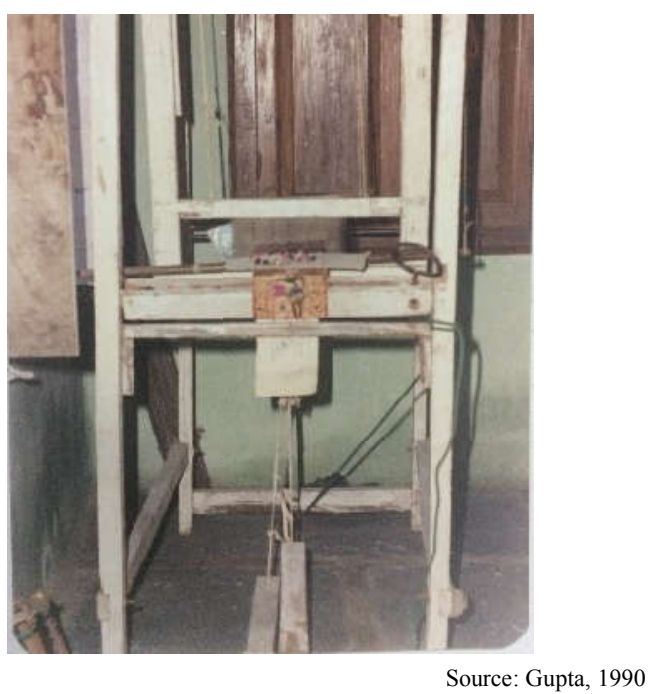

Fig. 9 Smaller loom for borders

Paithani sarees are silks in which there is no extra weft forming figures. The figuring weave was obtained by a plain tapestry technique. There are three techniques of weaving;

Split tapestry weave - the simplest weave where two weft threads are woven up to adjacent warp threads and then reversed. The warp threads are then cut and retied to a different color (Fig.10).

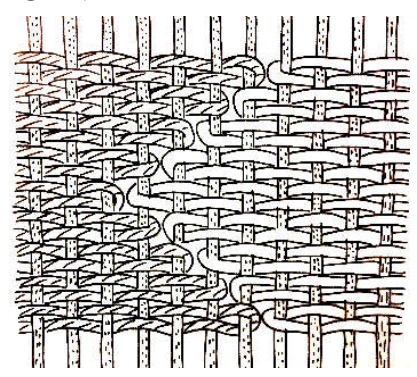

Fig.10 Split tapestry weave

Interlocking method - two wefts are interlocked with each other where the color change is required. The figuring weft is made of a number of colored threads, Plain weaving is done with the ground weft as gold threads This system of 
interlocking weaves, known as kadiyal, is done so that there are no extra floats on the back of the motif thus making the design nearly reversible (Fig.11).

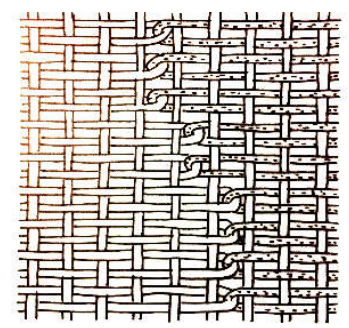

Fig.11 Interlocking method

Dove-tailing method - two threads go around the same warp, one above the other, creating a dove-tail or tooth-comb effect (Fig.12).

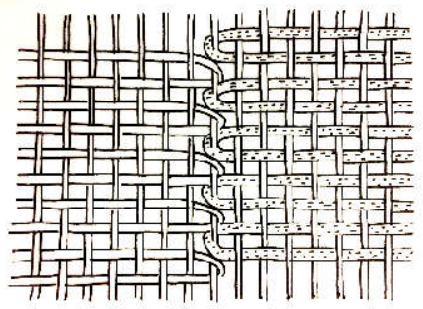

Fig.12 Dove-tailing method

Weaving could take between 18 and 24 months, depending upon the complexity of the design. Today there are many weavers who are working for the revival of this treasured weave (https://en.wikipedia.org/wiki/Paithani).

\section{Designs and motifs}

The designs were influenced by the Mughals and the Peshwas. Paithanis have evolved with the changing patronage of rulers. Many weavers draw inspiration from cave paintings, nature or from foreign lands.

The layout of a traditional paithani saree includes a pallav, which could be 16-36 inches in length depending on the design elaboration, border around 2-8 inches in width and an all over or alternate placement of small buti on the rest of the sari.

The pallav had a rectangular frame work with border on its four sides. The pallavat times was made entirely of gold and left plain. Very often motifs like flowers, branches with leaves, birds and geometric motifs were placed on pallav. Some popular border and pallavmotifs were:

Fruits and flowers: These were the most commonly used motifs. Traditional motifs include Ajanta lotus (Fig.13) which uses about six to seven colours, Persian inspired pomegranate motif (Anarvel) (Fig.14), curvilinear flowers (Fig.15), various geometric floral motifs (Fig.16), vine of grapes, lotus brocade: lotus motifs are used in pallav and sometimes on the border (Fig.17), Asawali (a flower pot with a flowering plant) (Fig.18 and 19),geometric floral border (Akruti border) (Fig.20).

Other traditional floral motifs of Paithani include the Keyrivel (Vine and Mango) (Fig.21), Draskshavel (vine and grape), Gokarnavel (Vine and gokarna flowers), Narli (coconut) and Pankha (fan).

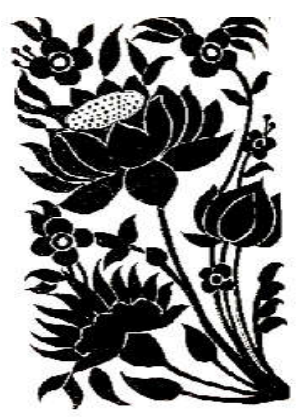

Fig. 13 Ajanta lotus

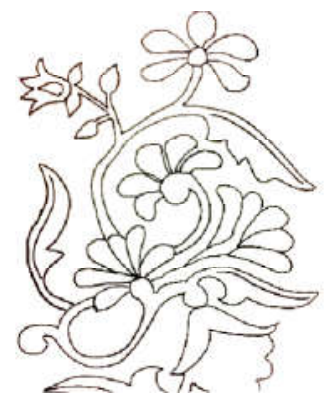

Fig.15 Curvilinear floral motifs

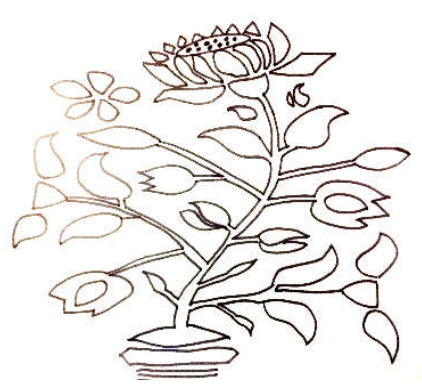

Fig.17 Lotus brocade

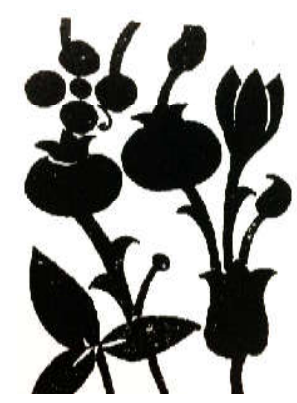

Fig.14 AnarVel

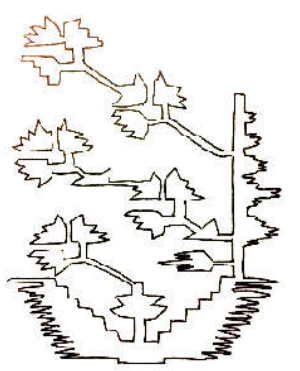

Fig.16 Geometric floral motif

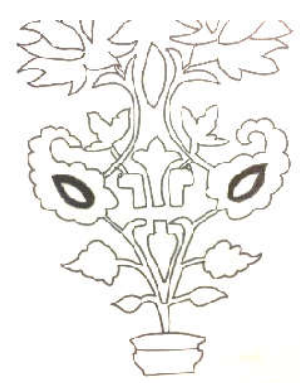

Fig.18 Asawali Motif

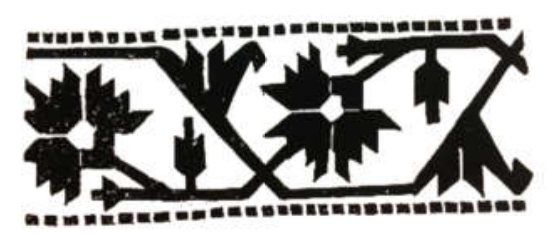

Fig.19 Asawali border

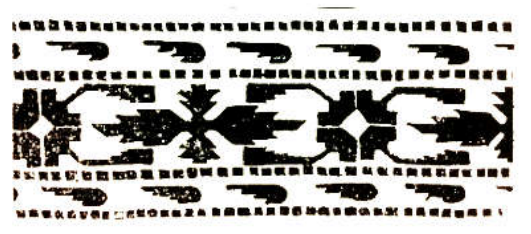

Fig.20 Akruti Border

Animals and birds: Motits like swan (Hans), peacock (Mor) (Fig.23), pair of birds (Totamaina) (Fig.24),border with parrots (popatvel) (Fig.25) were most popular traditional animal motifs. The border designs even of the same motif had to be created differently. The direction of the border weather horizontal or vertical influenced the direction of the motif being used (Fig.26). 


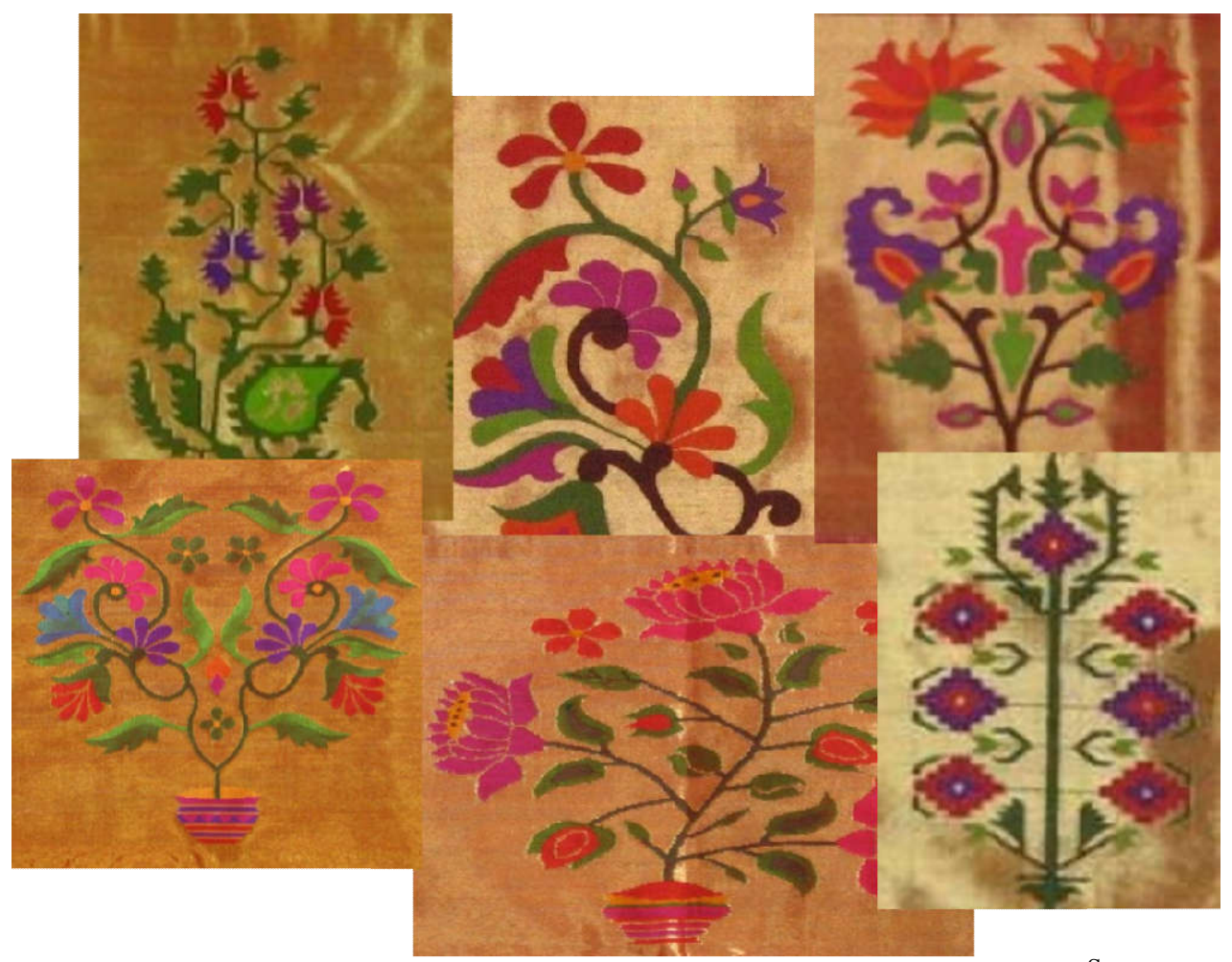

Fig.22 Traditional FloralPallav motifs

A peacock in a bangle (BangadiMor), woven onto the pallav, Munia (parrots woven inleaf green color) were very expensive because of the design. Muslims introduced designs like Behestiparinda (birds of paradise) and Huma parinda(the pheasant).

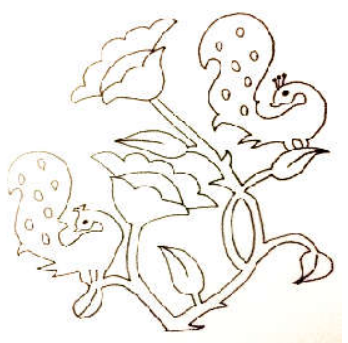

Fig 23 Mor

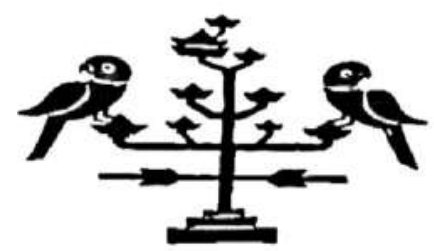

Fig.24 Tota Maina (pair of parrots)

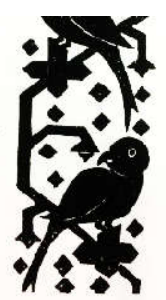

Fig. 25 PopatVel

Geometric motifs: Gold coin (Asharfi/Paisa) (Fig.27), Laher (design is done in the center to strengthen the zari), small motifs like geometric flower (akruti), stars etc. (Fig.27) were the popular butis for the body of the sari.The paisabuti was most often used and was very versatile as with its increasing and decreasing size it had varying significance.

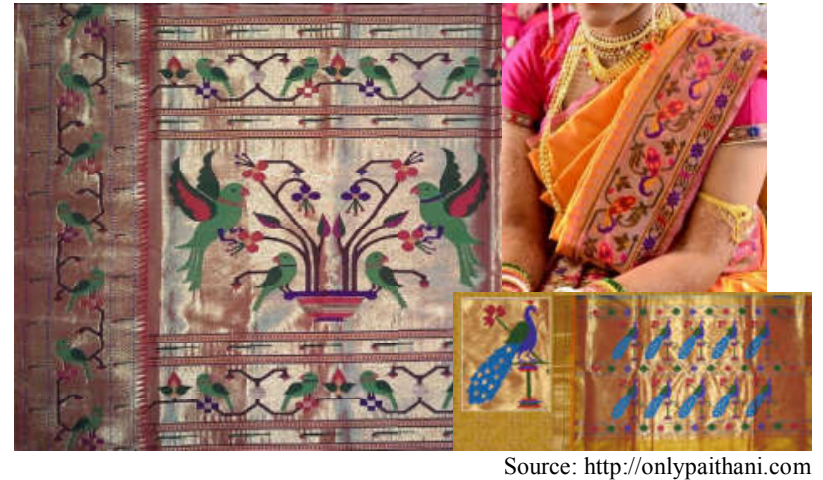

Fig.26 Traditional Animal border and Pallav Motifs

Larger paisabuti and traditional butis were worn by the brides as it signified Goddess Laxmi showering wealth.
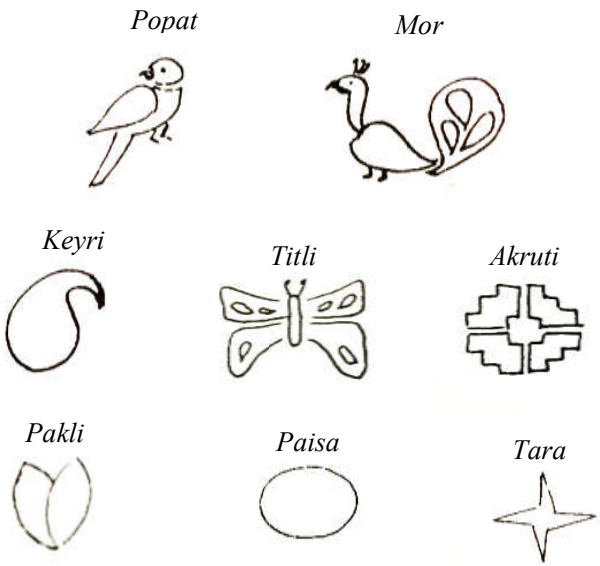

Fig. 27 Commonly used motifs for all over layouts 
Rui phool (cotton flower), clusters of 3 leaves, parrot (popat), peacock (mor), butterfly (titli) and paisley (keyri) were the traditionally used motifs for the body of the sari. Though the pallav and borders now made are not that elaborate but still the weavers are trying to keep their traditional motifs alive. Also, now use of artificial zari is seen in Paithanis mainly for the purpose of keeping it cost effective.

\section{Traditional Colours}

The use of indigenous dyes gave paithanis a quality of growth and enforcement. These colours permeated the fabrics and became its vital part. The paithanis have best expressed the refinement of colours in use of pure colours with soft tones and even the brighter shades. More than one shade was achieved by blending yarns of different colours during weaving such as black and red, black and white etc. The combinations used were Pasila (red,pink and green blends), Pheroze (white, red and pale green), Gujri (black and white), Mirani (black and red),Kusumbi (violet and red), Morpankhi (green blue blend). The colours used in paithani were Kaali Chandrakala( black), Ud-dani (fainter black), Neeligunji (sky blue),Motiya (peach pink), Pophali (yellow), Srirodak (white). Commonly usedcolourstoday are, red, lavender, purple, magenta, pearl, pink, green and saffron (Fig.28). The borders and the pallav are woven in zari regardless of the color of the sari (Jain 2008). found a site and named it Fatehnagar. It is said that in 1653 when Prince Aurangzeb was appointed the viceroy of the Deccan for the second time, he made Fatehnagar his capital and called it Aurangabad.

References of Kimkhab or the fabric of dreams in the accounts of Aurangzeb's rule during the $17^{\text {th }}$ century. The fabricwas very popular with the kings, ministers and the Nizams. It was made with rich gold and silk threads. Kimkhab was interweaving of silk and rich gold threads in a rich variety of colours and floral designs which made the brocades appear most gorgeous and one of the highly prized silk fabrics of India's legendary heritage.The Indian craftsmen made silver and gold wires of such extreme fineness that the entire fabric could be woven from them, producing literally a cloth of gold (Gillow and Barnard, 1993).

With the decline of Mughal and Maratha power the demand for Kimkhabwas drastically reduced. Fortunately, several craftsmen received patronage from the Nizam of Hyderabad and his ministers. The new consumers who mostly belonged to the middle classes could not afford the expensive and gorgeous cloth. Hence, weavers altered from their traditional material to silk and cotton and a look alike started to be made. It was called 'Hum-Roop' or similar. This new cloth was an imitation of the old rich Kimkhabas designs continued to be the same.

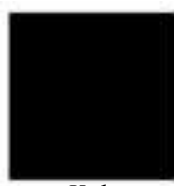

Kali

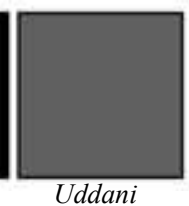

Uddani

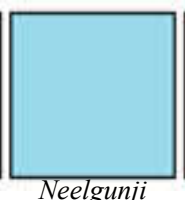

Neelgunji

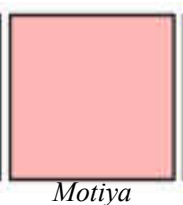

Motiya

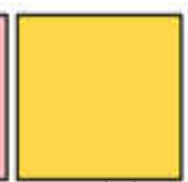

Pophali

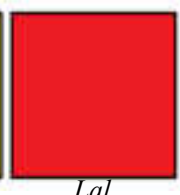

Lal

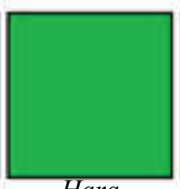

Hara

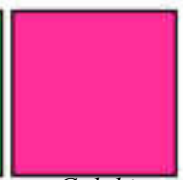

Gulabi

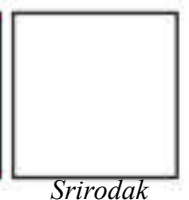

Srirodak

Fig.28 Colours of Paithani

\section{Himroo}

Another exquisite woven craft belonging to Aurangabad is the Himroo weaving. Paithanis and Himroo share common master crafts person, type of loom and working environment, yet the end product is vastly different. It's the skill of the weavers that they are able to produce such different textiles beautifully. It takes an enormous amount of capability to be expert in two different crafts.

Weaving of Himroowas one of the earliest industries of Aurangabad in Maharashtra. 'Himroo' is a fabric of intricate weave. In the past, these fabrics had a superior brightness and elegance since they were woven in the background of silk.

The antiquity of traditional Himroo weaving can be drawn out from two legendsthat contribute in tracing the origin ofHimroo. Firstly, it is known thatHimroo weaving is said to have been brought to Devagiri (present day Aurangabad) during Mohommad Bin Tughlaq's reign. He renamed Devagiri as Daulatabad and shifted the capital from Delhi to Daulatabad in 1326. He insisted that all industries should also be shifted to the new capital. A number of craftsmen shifted to Daulatabad and established the first industry in the city. Mohommad Bin Tughlaq's experiment gradually failed and the capital was shifted back to Delhi in 1335. However, by then the Himroo weavers got well settled in Daulatabad and continued their tradition in the same place (Moin, 2014).

Yet another record states thatMalik Ambar, the Prime Minister of Murtaza Nizam Shah of Ahmadnagar in 1610,
Hum-roopwas later connoted to Himroo and the fabric which was once known as Kimkhabunderwent a change and assumed the nameHimroo.Himroo is a fabric of intricate weave, woven in cotton warp and silk or artificial silk or rayon weft.

Himroo in those days was patronized by the royals and princely class who demanded the rich handloom textiles. To meet the royal demands, the entire Nawabpura area of Aurangabad echoed and reverberated to the sounds of shuttles moving up and down and nearly 500-600 looms were working in town (Bhandari, 2000).

\section{Traditional Himroo}

Persian motifs were adapted by Indian craftsmen to suit regional demands and made it subservient to the earthier and vibrant qualities of Indian art as a whole. Motifs and texture were excelled and eclipsed by glamorous Indian motifs. The texture on the fabric was so fine that it was compared to a spider's web.

Himroo usually has an all-over motif placement. Some patterns have specific names. The SiaJangla consisting of hanging creeper with flowers and foliage mixed up with miniature cones, Ajanta pattern inspired from Ajanta Caves and $A m b i$ pattern where paisley motif is themain component of design (Fig.29).

Besides the above mentioned patterns, there are many designs that can be woven on the Himroocloth. These include simple designs composed of lines, geometrical designs consisting of 
circles, diamonds, hexagons etc., designs of fruits like mango, pomegranates, almonds, flowers like rose, jasmine, lotus, chameli, creepers with leaves and stems connecting one another to form a running creeper and also birds and animals like elephant, peacocks (Sharma, V, 1998).

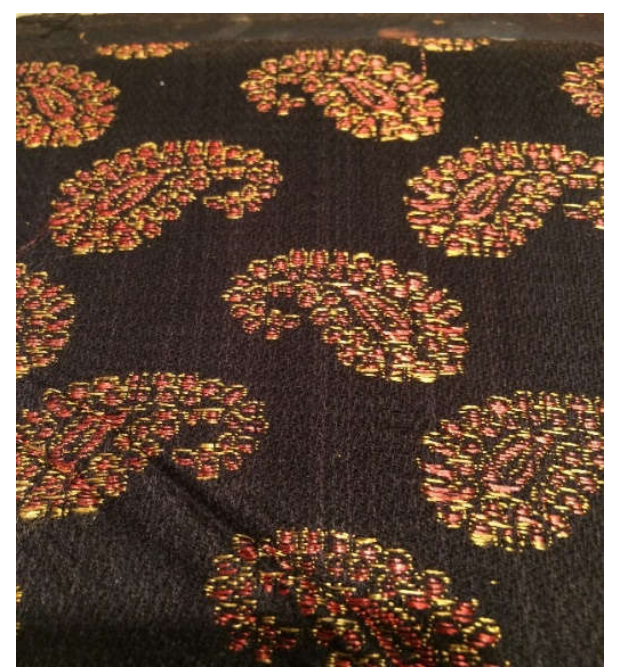

Source: Krishna, 2006

Fig. 29 Ambi pattern design

With an ethereal synthesis of cotton and silk, this handwoven fabric has superb blends of green, blue, black, gold and other romantic colour combination, that were once upon a time made-to-order by the royal household, nobles and courtiers.

The ground ofHimroois of uniform colour, usually black, pale slate or mustard and the patterns are picked out in pink, red, yellow and white, according to the ground colour.

Himroo has a quality which was much appreciated by the royalty. Nizams of Hyderabad used the Himroofabric for shervanis, coats, jackets, gowns, shirts and blouses. In fact, it became a part of their tradition and culture and no royal marriage was considered complete without the lavish use of Himroocloth.

\section{CONCLUSION}

Maharashtra is famous for its traditional handloom weaving since ages. It is a vast textile hub. Aurangabad, a district of Maharashtra, with its archaeological sites and ancient monuments provides the tourists a deep revelation of the wonders of its glorious past. Two of the most popular textiles belonging to this region include Himroo and Paithani.

The Paithanis are characterised by clean geometric or fluid lines. These designs have drawn inspiration from nature and changing surrounding. Indigenous dyes skilfully used provided durability and quality to the sari of the past. Traditional designs and colours continue to be followed with some changes. Colours have become brighter and designs simpler.

Himroo on the other handis considered one of the oldest handwoven textile of this regionand still holds a place of its own amid variegated designs and rare textures that adds to our Indian heritage.Himroo is patterned all over with Persian inspired motifs with both floral and animal figures designs. Raw materials used are cotton as warp and silk weft. Use of bright colours for designs and duller shades for base are used.
Both these exquisite crafts share the same set of skilled master weavers and pit loom. The varied difference between the end products (Fig. 31) of these two crafts of Aurangabad is due to use of different raw material, Paithanis use silk and Zari while Himroo requires cotton and silk. Also, different weaving method, design and motif placement adds to the contrast in both crafts. Paithani uses a lot of bright silk colours and gold zari and hence is very bright and glamourous. On the other hand, Himroo is made using subtle colours and can be considered more elegant as compared to Paithani. Though some similarities can be seen in traditional motifs of both the woven crafts, like the paisley pattern (Fig.30), lotus design, set of parrots and small geometric designs are found in both Paithani and Himroo in different stylised forms. Also, both these crafts are associated with the royality and are considered luxurious textiles for special occasions.
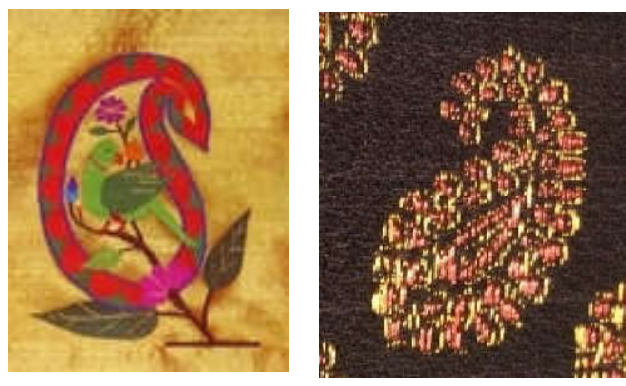

Source: www.touchofclass.com Source: Krisna,2006 Fig.30 Paisley motif of Paithani and Himroo
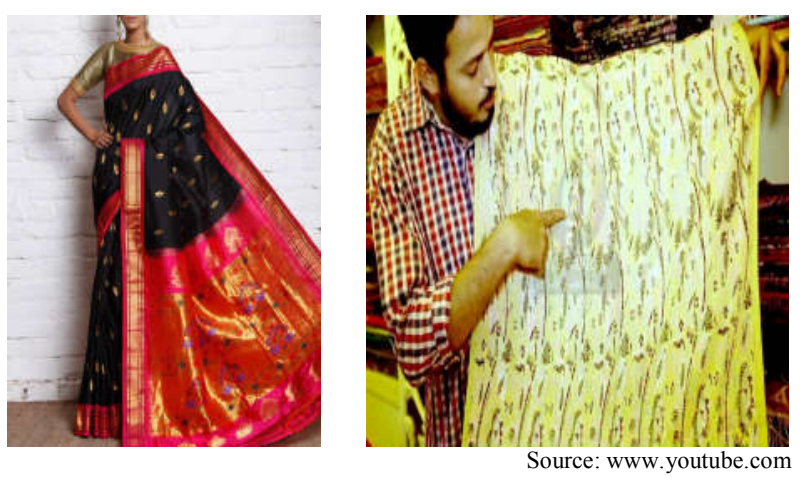

Fig.31 End product: Paithani Saree and Himrooshawl

Presently now with keen competition of power looms a lot of traditional crafts are fighting for its survival. Paithani has sustained itself through product development. It has entered markets of home textiles, accessories like bags, wallets etc. On the other hand, Himroo is a languishing craft of Aurangabad due to lesser number oftrained master weavers practising the craft.

\section{References}

Adanur, Sabit, 2001, Handbook of Weavimg, Technomic Publishing Company, 851 new Holland Ave, Pennsylvania, 17601.

Aggarwal, Yashodhara, 2008, Silk Brocades, Lustre press, Roli Books, M75 GK II market, ND 110048, India.

Anonymous, 1980, Treasures of Indian textiles, Calico museum, Ahmedabad, Marg publications, Army \& Navy Building, 3rd Floor, 148, Mahatma Gandhi RoadMumbai 400001, India. 
Anonymous, 1996, Indian Textiles, National Museum publications, Janpath, New Delhi.

Barnes, Ruth, Cohen, Steven and Crill, Rosemary, 2013, Trade Temple and Court, 10, Bezzola Complex, Opp. Suman Nagar, Sion Trombay Road, Chembur, Mumbai-400071, India India Book house pvt. Ltd.

Bhandari, Vandana, 2015, Jewelled textiles, Gold and Silver embellished cloth of India, Om Books International, A-12, Sector 64, Noida 201301, UP, India.

Bhandari, Vandana, 2004, Textiles and crafts of India, National institute of fashion technology, Prakash Book Depot, M-8L, Connaught Circus, ND 110001, India.

Bhatia, Reena and Desai, Deepti, Sustaining the traditional Paithanisaree weaving ofMaharashtra, India.

Published in International Conference on Innovative Trends in Multidisciplinary Academic Research, Vol1.

Chattopadhyaya, K.D., 1963, Indian Handicrafts, Allied Publishers Private Ltd, 1/13-14, Asaf Ali road, New Delhi 110002.

Cort, Cunningham, 2005, The Brocades of Banars, $19^{\text {th }}$ and $20^{\text {th }}$ Century, Arizona Publications, 62/1 DDA market, Opp JNU, Delhi.

Dhamija, Jasleen, 1990, Handwoven Fabrics of India, Mapin Publishing Pvt. Ltd., Chidambaram, Ahmedabad, 380013, India.

Dhamija, Jasleen, 2014, Sacred textiles of India, Marg foundation, Army and Navy Building, $3^{\text {rd }}$ floor, 148 MG road, Mumbai 400001, India.

Ellena, Berenice, 2006, Indian Sutra; A magical trail of textiles, Shubhi publications, LG 5, The Grand Mall, MG Road, Gurgaon 122002, India.

Gillow, John and Barnard, Nicholas, Indian Textiles, 2014, Om books International, A-12, Sector 64, Noida 201301, UP, India.

Gillow and Barnard, 1993, Traditional Indian Textiles, Thames and Hudson, 181A High Holborn, London.

Gupta, Charu, 1990, Art of paithani weaving- past and present, Department of Textile and Clothing, Lady Irwin College, Delhi University, Unpublished.

Harvey, Janet, 1997, Traditional Textiles of Central Asia, Thames and Hudson, 181A High Holborn, London.

Hatanaka, Kokya, 1997, Textile Arts of India, Chronicle Books, 275 fifth street, San Francisco, California, 94103.

Jacob, Robinet, 2005, Abhijeet Publications, 2/46, TukhmeerpurExtn, Delhi 110094.

Jaitly, Jaya, 2014, Craft Atlas of India, Niyogi Books, D78, Okhla Industrial Area, Phase I, Delhi 110020.

Jain, Rahul, 2008, Woven Textiles, Sarabhai Foundation, opp. Under bridge, Sahibag, Ahmedabad, 360004, India.

Jaitly, Jaya, 2012, Crafts of India,Niyogi books, D78, Okhla Industrial Area, phase 1, ND 110020, India.

Katiyar, Vijai S., 2009, Indian Saris; Traditional Perspective and Design, Wisdom tree, 4779/23, Ansari road, Daryaganj, ND 110002, India.

Krishna, Rai and Krishna, Vijay, 2006, Brocades, Crafts Museum, Delhi.

Kumar, Ritu, 1999, Costumes and Textiles of Royal India, Antique collectors club, Sanylane, woodbridge, IP12 4SD, UK.
Lebeau, Caroline, 1994, Fabrics; The Decorative Art of Textiles, Thames and Hudson, 181A High Holborn, London.

Lynton, Lynda, 2002, The Sari, Thames and Hudson, 181A High Holborn, London.

Murphy, W.S., 2000, Handbook of Weaving, Abhishek Publications, Sec-17C, Chandigarh.

Nambiar, A.C.K., 1996, Handloom Industry in India, APH publishing corporation, Ansari raod, Daryaganj, Delhi.

Rangaswamy, Vijaya, 1985, Textiles and Weaves in Medieval South India, Oxford university press, YMCA Library Building, 1st Floor, 1 Jai Singh Road, New Delhi 110001, India.

Ranjan, Aditi and Ranjan, M.P., 2007, Crafts of India; Handmade in India, Council of handicraft development corporation, New Delhi, India.

Reeves, Ruth, 1967, Folk Arts of India; Metal, Ceramic, Jewellery, Textiles and Wood, School of Arts, Syracuse University, New York.

Quazi, Moin, 2014, Woven Wonders of the Deccan, Notion Press, 38, MC Nicholas road, Chetpet, Chennai, Tamil Nadu, 600031.

Sanani Manohar, 2001, Encyclopedia of Tourism, Resource in India, Gyan Publication, 23 main Ansari road, Daryaganj, Delhi 110002.

Sanyal, Amba, 1989, Saris of India, Madhya Pradesh, Wiley Eastern Ltd and Amr VastraKosh II, Haus Khas Village, ND 110016, India.

Saraswathi, S.K.,2004, Indian Textiles, Publication Division, Ministry of Information and Broadcasting, Government of India.

Sharma,V, 1998, Studies in Indian Textiles, Bhartiya Kala Prakashan, 3611/5, Narang Colony, Tri Nagar, Delhi 110035.

Singh, Martand, 2001, The Master Weavers, Tata Press Ltd, 414, Veer Savarkar Marg, Prabhavati, Mumbai.

The Indian Institute of Art in industry, Design in Indian Textiles, Artistry house 15 park street, Calcutta, India.

\section{Websites Visited}

- www.fiber2fashion.com

- www.indian-heritage.org

- www.wikipedia.com

- www.india-craft.com

- https://books.google.co.in/ paithaniweaving

- www.aurangabad..nic.in

- www.maharashtratourism.gov.in

- www.kapsepaithani.com

- www.handloomofindia.com

- www.indrayanihandloom.com

- http://onlypaithani.com

- www.mapsofindia.com

- www.hampi.com

- www.touchofclass.com

- www.paithanibuta.com

- www.alamy.com

- www.youtube.com 